\title{
ASSESSMENT OF THE STATE OF GREENNESS AND SUGGESTIONS FOR ITS IMPROVEMENT IN PRISHTINA SCHOOLS IN KOSOVO
}

\author{
Gjok Vuksani ${ }^{1 *}$, Haki Kurti ${ }^{2}$ \\ ${ }^{1 *}$ Agricultural University of Tirana, Department of Horticulture and Landscape Architecture, Tirana, Albania; \\ ${ }^{2}$ Kosovo Agency of Statistics, Agriculture and Environment Statistics Department, Prishtina, Kosovo; \\ "Corresponding author: Gjok Vuksani, email: gjvuksani@ubt.edu.al; \\ Received May, 2018; Accepted June, 2018; Published July, 2018; \\ DOI: https://doi.org/10.31407/ijees8408 \\ UOI license: http://u-o-i.org/1.01/ijees/75226596
}

\begin{abstract}
The aim of the study is assessment of the condition of greenness in Prishtina schools and its positive role in students' life. Prishtina is the capital of the Republic of Kosovo, extending in the eastern part of Kosovo, in the geographical latitude of $42^{\circ}, 40^{\prime}, 00$ "and the geographical longitude of $21^{\circ} 20^{\prime} 15^{\prime \prime}$ with a surface of $572 \mathrm{~km}^{2}$. The altitude ranges from $585 \mathrm{~m}, 640,670$ and about $700 \mathrm{~m}$ above sea level in some neighborhoods of the city. In Prishtina, the continental climate dominates. This study was conducted in lower secondary schools and upper secondary schools in Prishtina with a total of 38,232 pupils.In our study, we have focused on green spaces because they have an irreplaceable role, especially in the lives of children, as they have a positive effect on noise reduction, air quality improvement, air filtration from the dust, beautify the environment, lower high temperatures, reduces stress and depression, etc. For the assessment of the condition of green spaces in Prishtina schools, we were based on the Quantitative Assessment Method according to Barbosa et al. 2007, Wang 2009 [1], but also combined with the Williams and Green Quality Assessment Method (2001) [2] such as assessing the type and quality of vegetation, the safety of green spaces for children, etc.There are no defined objective criteria that can be followed for the assessment of green space, but we have combined the evaluation of quantitative and qualitative criteria so the conclusions that we will find to be more understandable and acceptable to the beneficiaries for greenness and decision-making bodies. Dozens of expeditions have been conducted on the field, where there were taken photographs and collection of floristic material, study of the state and types of greenery in all schools have been made.Our research work is supported by the data provided by the Ministry of Education, Science and Technology (MEST) and the principals of primary and secondary schools for the greenhouse inventory in the respective schools of Prishtina.Prishtina map and location of green spaces of schools were designed with the SIG (Geographic Information System) program.From the detailed study we can conclude that the green areas of Prishtina schools are very scarce, minimum $15 \mathrm{~m}^{2}$ up to $2900 \mathrm{~m}^{2}$, with a much reduced area for students, who in most schools do not even get $1 \mathrm{~m}^{2} /$ student. We point out that in the structure of grown plants in green areas, the highest percentage occupy the flowers (Petunia spp., Begonia spp., Zinnia spp., Viola spp., Rosa spp. and Lilium spp.) up to $96 \%$ of all vegetation. Decorative shrubs occupy most of the space of the perennial plants because of the reduced surface available for greenness and the impossibility of planting tall plants because they will take large space. Among the tall plants, dominating the green spaces in Prishtina schools are: Linden (Tilia platyphylia and Tilia cordata), Thuja occidentalis 'Smaragd', Thuja pyramidalis, Picea abies etc.
\end{abstract}

Key words: Green spaces, schools, health benefits, educational benefits. 